\title{
Mass Spectral Fragmentation Pattern of N,N' -Diphenylformamidines
}

\author{
Neil G. Keats, Jean E. Rockley, and Lindsay A. Summers \\ Department of Chemistry, The University of Newcastle, 2308, New South Wales, Australia \\ (Z. Naturforsch. 32 b, 1156-1159 [1977]; received June 27, 1977)
}

Mass Spectra, N,N'-Diphenylformamidine, $\mathrm{N}, \mathrm{N}^{\prime}$-Di(chlorophenyl)formamidines

The base peaks in the mass spectra of $\mathrm{N}, \mathrm{N}^{\prime}$-diphenylformamidine, $\mathrm{N}, \mathrm{N}^{\prime}$-di-(4-chlorophenyl)formamidine and $\mathrm{N}, \mathrm{N}^{\prime}$-di-(3-chlorophenyl)formamidine are due to the molecular ions of aniline, 4-chloroaniline and 3-chloroaniline respectively. The species responsible for the base peaks are thought to be formed by rupture of the $\mathrm{CH}-\mathrm{NH}$ bond with concomitant hydrogen migration.

There has been very little investigation of the mass spectral fragmentation of formamidines on electron impact ${ }^{1}$. The rearrangement processes involved in the fragmentation of N,N-dimethyl- $\mathrm{N}^{\prime}$ phenylformamidines have been the subject of some study ${ }^{2-6}$ but there has been no report of the fragmentation of simple formamidines. This paper is concerned with the mass spectral fragmentation of $\mathrm{N}, \mathrm{N}^{\prime}$-diphenylformamidine (1) and two symmetrically substituted $\mathrm{N}, \mathrm{N}^{\prime}$-di(chlorophenyl)formamidines (2) and (3).

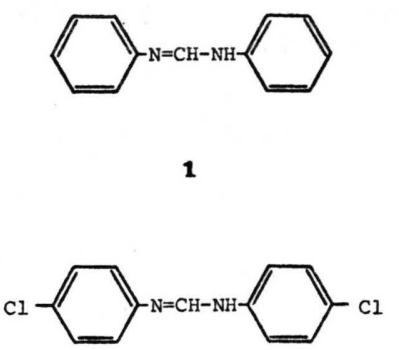

2

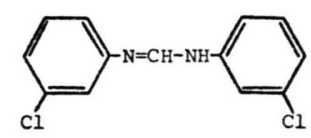

3

Requests for reprints should be sent to Prof. Dr. L. A. Summers, Department of Chemistry, The University of Newcastle, 2308, New South Wales, Australia.
The base peak in the spectrum of $\mathrm{N}, \mathrm{N}^{\prime}$-diphenylformamidine (1) (Fig. 1) is not due to the molecular ion at mass 196. The base peak is at mass 93 due to a species of formula $\mathrm{C}_{6} \mathrm{H}_{7} \mathrm{~N}^{\oplus}$. The molecular ion at mass 196 gives rise to a peak of $41 \%$ of the intensity of the base peak. Loss of $\mathrm{H}^{\cdot}$ from the molecular ion gives the M-1 ion which is responsible for the peak at mass $195(11 \%)$.

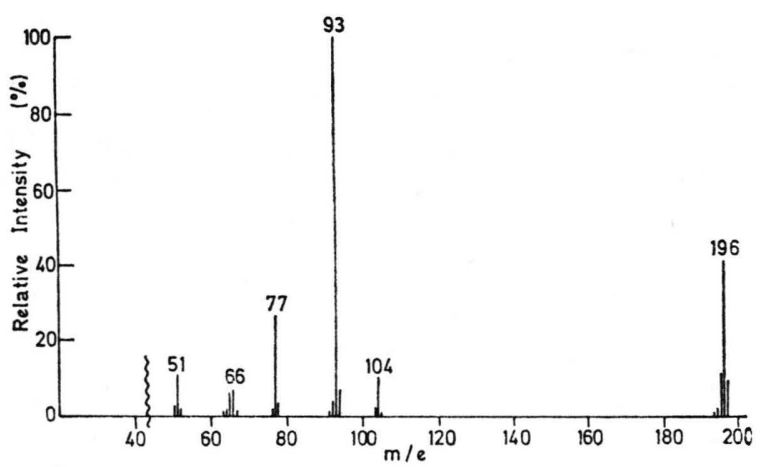

Fig. 1. Mass spectrum of $\mathrm{N}, \mathrm{N}^{\prime}$-diphenylformamidine.

The fragmentation pattern of $\mathrm{N}, \mathrm{N}^{\prime}$-diphenylformamidine (1) (Scheme) is an interesting one. The initial disintegration of the molecular ion of $\mathbf{1}$ at mass 196 involves rupture of the $\mathrm{CH}-\mathrm{NH}$ bond to afford the two fragments at mass $104(10 \%)$ and $92(4 \%)$ due to $\mathrm{C}_{7} \mathrm{H}_{6} \mathrm{~N}^{\oplus}$ and $\mathrm{C}_{6} \mathrm{H}_{6} \mathrm{~N}^{\oplus}$ ions respectively. This bond rupture, however, may be accompanied by a hydrogen migration to afford the two species at mass $103(2 \%)$ and $93(100 \%)$ of empirical formula $\mathrm{C}_{7} \mathrm{H}_{5} \mathrm{~N}^{\oplus}$. and $\mathrm{C}_{6} \mathrm{H}_{7} \mathrm{~N}^{\oplus}$. depicted as the phenylisocyanide and aniline molecular ions respectively. A strong metastable peak in the 


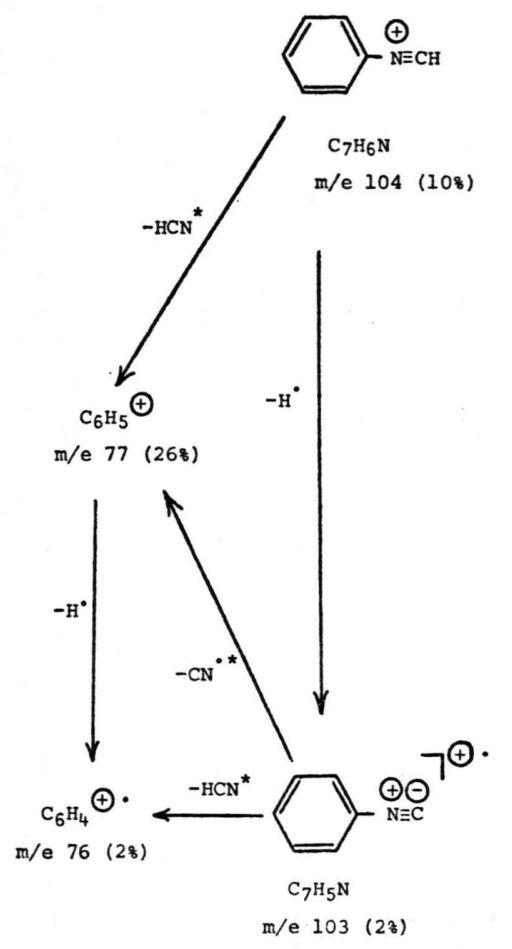

spectrum at mass 44.2 corresponds to the transition $196 \rightarrow 93$. The aniline molecular ion (at mass 93) which is known to be a very stable one ${ }^{7}$ is in fact the base peak in the spectrum of $\mathrm{N}, \mathrm{N}^{\prime}$-diphenylformamidine.
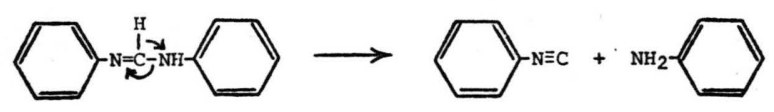

The subsequent fragmentation of the $\mathrm{C}_{7} \mathrm{H}_{6} \mathrm{~N}^{\oplus}$, $\mathrm{C}_{6} \mathrm{H}_{6} \mathrm{~N}^{\oplus}, \mathrm{C}_{7} \mathrm{H}_{5} \mathrm{~N}^{\oplus}$. and $\mathrm{C}_{6} \mathrm{H}_{7} \mathrm{~N}^{\oplus \cdot}$ species involves the loss of HCN in each case. Metastable peaks are observed for these transitions. This results in the formation of the species giving rise to peaks at mass $77\left(26 \% ; \mathrm{C}_{6} \mathrm{H}_{5}^{\oplus}\right), 65\left(6 \% ; \mathrm{C}_{5} \mathrm{H}_{5} \oplus\right), 76\left(2 \% ; \mathrm{C}_{6} \mathrm{H}_{4}^{\oplus \cdot}\right)$ and $66\left(7 \% ; \mathrm{C}_{5} \mathrm{H}_{6}{ }^{\oplus}\right)$. The species considered to be the phenylisocyanide molecular ion at mass 103 $\left(\mathrm{C}_{7} \mathrm{H}_{5} \mathrm{~N}^{\oplus \cdot}\right)$ may also lose $\mathrm{CN} \cdot\left(c f .{ }^{8}\right)$ and this fragmentation route provides another source of the $\mathrm{C}_{6} \mathrm{H}_{5} \oplus$ ion at mass 77 . Successive losses of $\mathrm{H} \cdot$ from the $\mathrm{C}_{5} \mathrm{H}_{5} \oplus$ ion at mass 65 account for the small peaks $(1-2 \%)$ at mass $64\left(\mathrm{C}_{5} \mathrm{H}_{4}^{\oplus \cdot}\right)$ and $63\left(\mathrm{C}_{5} \mathrm{H}_{3}^{\oplus}\right)$. The peaks below a mass of 60 in the spectrum are typical of those to be expected from further disintegration of the species shown in the Scheme and require no comment.
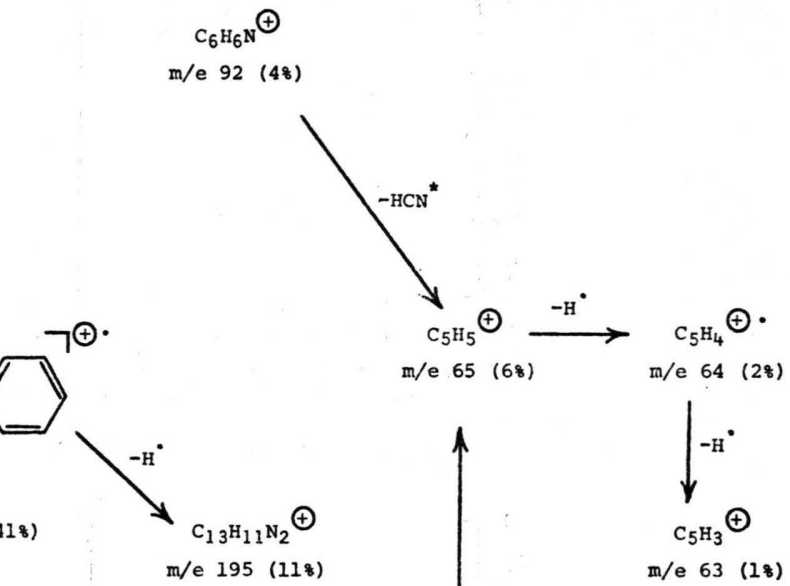

me $65(68)$

Table 1. Empirical formula of fragment ions* in the mass spectrum of $\mathrm{N}, \mathrm{N}^{\prime}$-diphenylformamidine (1).

\begin{tabular}{rlr}
\hline$m / e$ & Formula & Intensity [\%] \\
\hline 196 & $\mathrm{C}_{13} \mathrm{H}_{12} \mathrm{~N}_{2}$ & 41 \\
195 & $\mathrm{C}_{13} \mathrm{H}_{11} \mathrm{~N}_{2}$ & 11 \\
194 & $\mathrm{C}_{13} \mathrm{H}_{10} \mathrm{~N}_{2}$ & 2 \\
104 & $\mathrm{C}_{7} \mathrm{H}_{6} \mathrm{~N}$ & 10 \\
103 & $\mathrm{C}_{7} \mathrm{H}_{5} \mathrm{~N}$ & 2 \\
93 & $\mathrm{C}_{6} \mathrm{H}_{7} \mathrm{~N}$ & 100 \\
92 & $\mathrm{C}_{6} \mathrm{H}_{6} \mathrm{~N}$ & 4 \\
91 & $\mathrm{C}_{6} \mathrm{H}_{5} \mathrm{~N}$ & 1 \\
77 & $\mathrm{C}_{6} \mathrm{H}_{5}$ & 26 \\
76 & $\mathrm{C}_{6} \mathrm{H}_{4}$ & 2 \\
66 & $\mathrm{C}_{5} \mathrm{H}_{6}$ & 7 \\
65 & $\mathrm{C}_{5} \mathrm{H}_{5}$ & 6 \\
64 & $\mathrm{C}_{5} \mathrm{H}_{4}$ & 2 \\
63 & $\mathrm{C}_{5} \mathrm{H}_{3}$ & 1 \\
51 & $\mathrm{C}_{4} \mathrm{H}_{3}$ & 11 \\
50 & $\mathrm{C}_{4} \mathrm{H}_{2}$ & 3 \\
\hline
\end{tabular}

* Only those ions of mass $>49$ and of intensity $\geqslant 1 \%$ of the base peak are recorded. Peaks due to ${ }^{13} \mathrm{C}$ species are omitted from the table.

The spectra of N,N'-di-(4-chlorophenyl)-formamidine (2) (Fig. 2) and N,N'-di-(3-chlorophenyl)formamidine (3) (Fig. 3) are very similar and their fragmentation pathways follow much the same route as that observed with $\mathrm{N}, \mathrm{N}^{\prime}$-diphenylformamidine (1). In both cases the base peak is at mass 


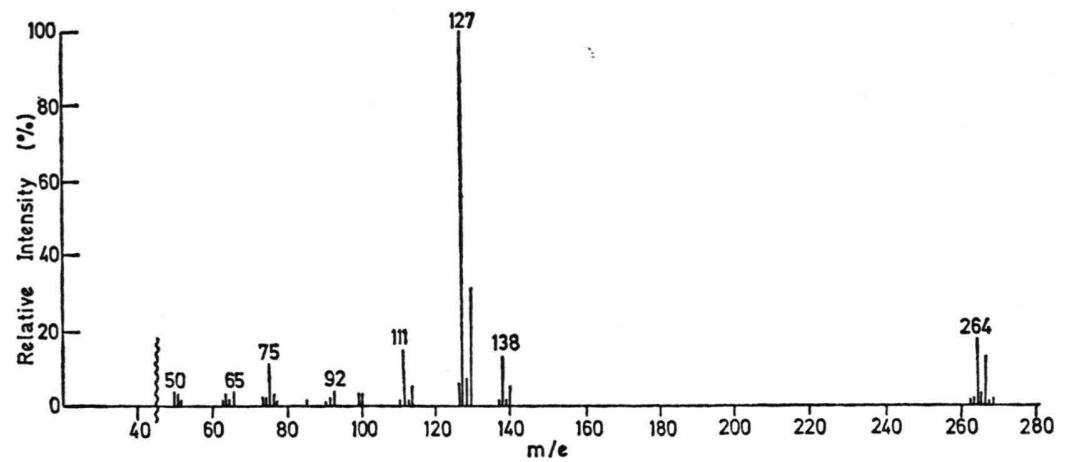

Fig. 2. Mass spectrum of $\mathrm{N}, \mathrm{N}^{\prime}$-di-(4-chlorophenyl)-formamidine.

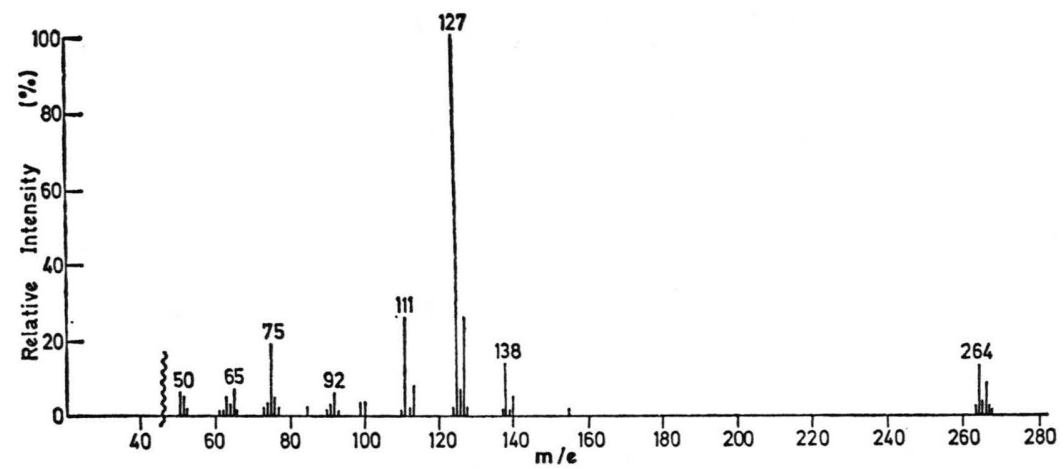

Fig. 3. Mass spectrum of $\mathrm{N}, \mathrm{N}^{\prime}$-di-(3-chlorophenyl)-formamidine.

127 due to the molecular ion of the corresponding chloroaniline of formula $\mathrm{C}_{6} \mathrm{H}_{6} \mathrm{NCl}$. The molecular ion of the di-(chlorophenyl)-formamidines at mass 264 gives rise to a peak of $18 \%$ of the intensity of the base peak with the 4-chloro derivative (2) and $14 \%$ of the intensity of the base peak with the 3 -chloro analogue (3). The peaks at mass $138(13 \%$; $\left.\mathrm{C}_{7} \mathrm{H}_{5} \mathrm{NCl}^{\oplus}\right)$ and mass $126\left(2-6 \% ; \mathrm{C}_{6} \mathrm{H}_{5} \mathrm{NCl}^{\oplus}\right)$ are likewise considered to arise largely by rupture of the $\mathrm{CH}-\mathrm{NH}$ bond while those at mass $137(1 \%$; $\left.\mathrm{C}_{7} \mathrm{H}_{4} \mathrm{NCl}^{\oplus \cdot}\right)$ and $127\left(100 \% ; \mathrm{C}_{6} \mathrm{H}_{6} \mathrm{NCl}^{\oplus \cdot}\right)$ are formed by hydrogen migration accompanying the rupture of this bond. The peaks at mass $111(15-26 \%$; $\left.\mathrm{C}_{6} \mathrm{H}_{4} \mathrm{Cl}{ }^{\oplus}\right), 99\left(3 \% ; \mathrm{C}_{5} \mathrm{H}_{4} \mathrm{Cl}{ }^{\oplus}\right), 110\left(1 \% ; \mathrm{C}_{6} \mathrm{H}_{3} \mathrm{Cl}^{\oplus}\right.$.), and $100\left(3 \% ; \mathrm{C}_{5} \mathrm{H}_{5} \mathrm{Cl}^{\oplus \cdot}\right)$ may be formed by subsequent loss of HCN but metastable peaks were observed only for the transitions $138 \rightarrow 111$ and $127 \rightarrow 100$. It is interesting to note that the central bond rupture occurs before loss of $\mathrm{Cl}$. from the molecular ions of 2 and 3 . The peaks below a mass of 99 in the spectra of 2 and 3 require little comment (see Table II). They are typical of those to be expected from benzene, chlorobenzene and chloroaniline derivatives.
Table II. Empirical formula of fragment ions* in the mass spectra of $\mathrm{N}, \mathrm{N}^{\prime}$-di-(chlorophenyl)-formamidines.

\begin{tabular}{rlrr}
\hline$m / e$ & Formula & \multicolumn{2}{r}{ Intensity $[\%]$} \\
\hline & & 2 & 3 \\
266 & $\mathrm{C}_{13} \mathrm{H}_{10}{ }^{37} \mathrm{Cl}_{2} \mathrm{~N}_{2}$ & 12 & 10 \\
140 & $\mathrm{C}_{13} \mathrm{H}_{10}{ }^{35} \mathrm{Cl}_{2} \mathrm{~N}_{2}$ & 18 & 14 \\
138 & $\mathrm{C}_{7} \mathrm{H}_{5}{ }^{37} \mathrm{ClN}$ & 5 & 5 \\
137 & $\mathrm{C}_{7} \mathrm{H}_{5}{ }^{35} \mathrm{ClN}$ & 13 & 13 \\
129 & $\mathrm{Cl}_{7} \mathrm{H}_{4}{ }^{35} \mathrm{ClN}$ & 1 & 1 \\
127 & $\mathrm{C}_{6} \mathrm{H}_{6}{ }^{37} \mathrm{ClN}$ & 31 & 26 \\
126 & $\mathrm{C}_{6} \mathrm{H}_{6}{ }^{35} \mathrm{ClN}$ & 100 & 100 \\
113 & $\mathrm{C}_{6} \mathrm{H}_{5}{ }^{35} \mathrm{ClN}$ & 6 & 2 \\
111 & $\mathrm{C}_{6} \mathrm{H}_{4}{ }^{37} \mathrm{Cl}$ & 5 & 8 \\
110 & $\mathrm{C}_{6} \mathrm{H}_{4}{ }^{35} \mathrm{Cl}$ & 15 & 28 \\
100 & $\mathrm{C}_{6} \mathrm{H}_{3}{ }^{35} \mathrm{Cl}$ & 1 & 1 \\
99 & $\mathrm{Cl}_{5} \mathrm{H}_{5}{ }^{35} \mathrm{Cl}$ & 3 & 3 \\
92 & $\mathrm{C}_{5} \mathrm{H}_{4}{ }^{35} \mathrm{Cl}$ & 3 & 3 \\
91 & $\mathrm{C}_{6} \mathrm{H}_{6} \mathrm{~N}$ & 4 & 6 \\
90 & $\mathrm{C}_{6} \mathrm{H}_{5} \mathrm{~N}$ & 2 & 3 \\
85 & $\mathrm{C}_{6} \mathrm{H}_{4} \mathrm{~N}$ & 1 & 1 \\
77 & $\mathrm{C}_{4} \mathrm{H}_{2}{ }^{35} \mathrm{Cl}$ & 1 & 1 \\
76 & $\mathrm{C}_{6} \mathrm{H}_{5}$ & 1 & 2 \\
75 & $\mathrm{C}_{6} \mathrm{H}_{4}$ & 2 & 4 \\
74 & $\mathrm{C}_{6} \mathrm{H}_{3}$ & 11 & 19 \\
73 & $\mathrm{C}_{6} \mathrm{H}_{2}$ & 2 & 3 \\
65 & $\mathrm{C}_{6} \mathrm{H}$ & 1 & 2 \\
64 & $\mathrm{C}_{5} \mathrm{H}_{5}$ & 4 & 6 \\
63 & $\mathrm{C}_{5} \mathrm{H}_{4}$ & 1 & 3 \\
62 & $\mathrm{C}_{5} \mathrm{H}_{3}$ & 3 & 5 \\
\hline & $\mathrm{C}_{5} \mathrm{H}_{2}$ & 1 & 1 \\
\hline
\end{tabular}

Only those ions of mass $>60$ and of intensity $\geqslant 1 \%$ species are omitted from the table. 


\section{Experimental}

The mass spectra were determined with an A.E.I. MS-30 mass spectrometer. The samples were analysed by a direct insertion probe at an ionizing current of $70 \mathrm{eV}$. The ion source temperature was

1 G. Häfelinger in S. Patai (ed.): The Chemistry of Amidines and Imidates, p. I, Wiley, New York 1975.

2 A. K. Bose, I. Kugajevsky, P. T. Funke, and K. G. DAS, Tetrahedron Lett. 1965, 3065.

3 H. F. Grützmacher and H. Kuschel, Org. Mass Spectrom. 3, 605 [1970].

$4 \mathrm{H}$. Kuschel and H. F. Grützmacher, Org. Mass Spectrom. 9, 395 [1974]. $140^{\circ} \mathrm{C}$. Elemental compositions were obtained by the peak matching method.

$\mathrm{N}, \mathrm{N}^{\prime}$-Diphenylformamidine, $\mathrm{N}, \mathrm{N}^{\prime}$-di-(4-chlorophenyl)-formamidine and N,N'-di-(3-chlorophenyl)formamidine were analytically pure.

5 H. Kuschel and H. F. Grützmacher, Org. Mass Spectrom. 9, 403 [1974].

$6 \mathrm{H}$. Kuschel and H. F. Grützmacher, Org. Mass Spectrom. 9, 408 [1974].

7 P. N. Rylander, S. Meyerson, E. L. Eliel, and

J. D. McCollum, J. Am. Chem. Soc. 85, 2723 [1963].

8 B. ZEEH, Org. Mass Spectrom. 1, 315 [1968]. 